the ruthlessness of natural selection and the fmprobabilities of the "embryo of AEt organic ereation". But at least the issue was not decided without much thought. Of all the four versions of the final verdict which have survived in these manuscripts, none is more characteristic than that which follows, in conclusion :

". . . But I now find that were I to attempt extending my notes on the subject they would form quite an essay ..., while my imperfect acquaintance with the science of the present day would to some extent disqualify them for publication in tre state they flowed from my pen. As mere suggestions to help a master mind they might perhaps be useful, but scarcely otherwise. But be that as it may, I am not by any means satisfied in my own mind that either of you have attained the desired goal though you attempt to reach it by such different routes. He [i.e. Darwin] starts from the present time and by a rigid process of induction argues that nature commenced her existirig animal kingdom by the creation of some 4 or 5 forms, her vegetable one by about as many primary vegetable forms thousands of years ago. Such is the process by which the patient and laborious Saxon go'es to work. The rapid thinking and impulsive Celt on the other hand, having caught sight of his theory in the distance, straightway bounds to prove by induction that it must be right. While the cautious Scotchman looks first at the one and then at the other and right or wrong thinks both have missed the mark and concludes that Moses is the profoundest Philosopher of the three since he is content to take things as he finds them and in one word declares all we know or are ever likely to know by saying God Created, without enquiring how".

\section{STRUCTURE AND EVOLUTION OF THE LEVANT AND NORTHERN AFRICA}

\author{
By DR. K. S. SANDFORD \\ University Museum, Oxford
}

$\mathrm{T}$ HE following notes are an attempt to recapitulate the essential stages in the development of the southern side of the western Tethys and of the Mediterranean. They refer particularly to Leo Picard's publications, especially "Structure and Evolution of Palestine, with Comparative Notes on Neighbouring Countries"*, from the point of view of the geologist who has some familiarity with north African problems. Much that is still in doubt and much of local significance must inevitably be omitted; nevertheless a broad review of this type may be useful at the present juncture.

At the end of the Pre-Cambrian, Palestine lay on the borders of a high (Upper Algonkian) mountain range in which earlier mountains and varied rock types were welded into a mountain mass: this may be traced from Arabia through Sinai and the Red Sea Hills into Africa ("Arabo-Nubian mass"). PrePalæozoic denudation reduced the mountains to a lowland with seas lying on the west and north, the latter being identified with an east-west Palæozoic sea. Marine Cambrian beds are recorded on the mainland mass of north-west Africa and of western Asia, and from the Cambrian to the Cenozoic there were farreaching transgressions across Mauritania, the Sahara,

* Structure and Evolution of Palestine: with Comparative Notes on Neighbouring Countries. By Leo Picard. (Bulletin of the Geological Department, Vol. 4, Nos. $2,3,4$.$) Pp. iv +134. (Jerusalem$ Geological Department, Hebrew University, 1943.)
Libya and Egypt into the interior of Africa, across Palestine into Arabia.

Durïng regresisive phases, widespread continental beds were laid down over areas formerly marine. As there was continuous subaerial denudation and accumulation over the land areas, stratigraphy there is concerned largely with the interdigitation of continuous and discontinuous subaerial deposits, lagoonal and marine beds. The shore-line, continually shifting, was frequently indented: the sea and its lagoons ran far into deep bays between promontories on which subaerial processes continued. The advances of the epicontinental seas might therefore be called, as Picard suggests, ingressions rather than transgressions. The major promontories were broadly related to swells or structural undulations, the locations of which in northerm Africa are plainly marked.

The continental beds consist for the most part of dune-sands and fluviatile quartz conglomerates : similar beds are now accumulating in the continental interiors of Arabia and northern Africa. Nubian Sandstone is an unfortunate term for these beds, in my opinion; Nubian facies expresses all that is desired : Nubia (in a broad sense) and lands to the south of it have probably been continental since the Pre-Cambrian.

Palæozoic transgressions (or ingressions) occurred in Palestine and adjoining territories in the Middle Cambrian, Ordovician, Silurian, Lower Devonian (?) and Lower Carboniferous (Sinai and on the Egyptian side of the Gulf of Suez) : the Silurian left graptolitebearing shales in Central Arabia.

In northern Africa the Palæozoic transgressions, Cambrian, Ordovician, Silurian, Lower-Upper Devonian, Lower Carboniferous seem to have come from the west rather than the north. The Silurian graptolite-bearing shales can be traced far into the interior, where they pass into sandstones. In w'estern Asia, as in northern Africa, the Carboniferous seems to have witnessed final Palæozoic regression. The Triassic palæography of Palestine was nevertheless related to that of the Palæozoic, with a shelf sea, transgressive from the nearly Tethys, in the Lower-Middle Trias, followed by Upper Triassic uplift and continental beds.

The north-western corner of the African shield, with its Palæozoic blankets, was involved in Hercyn. ean mountain building, and Triassic (or PermoTriassic) red beds with salt mark a stage in the ensuing denudation: except for small patches of lagoonal beds, the unfolded continental platform seems to be devoid of Triassic rocks.

In Sinai and Palestine there was renewed transgression of a Jurassic sea shallowing eastward: locally there are thick Bajocian-Kimmeridgian beds following a Lower Jurassic (Liassic) continental phase. Moreover, the uppermost Jurassic (Portlandian) beds appear to be regressive-continental, a condition which was maintained until Wealden (Lebanon - Palestine), Albian (Syria), or Cenomanian (Eastern Sinai-Transjordan) transgression supervened. The 'facies of the Nubian Sandstone' predominated during the regressive and transgressive phases; there was extensive volcanic activity and probably fracture in the transition from the Jurassic to the Cretaceous.

There is a small exposire of marine Jurassic beds on the Egyptian gide of the Gulf of Suez; otherwise they do not seem to be exposed in Egypt, Libya or the Sahara : some continental beds are known in Libya, and probably there are others. A new element is discernible however, namely, the Mesozoic sea of 
Barbary, where thick Jurassic sediments, mostly limestones, followed the Trias : they represent sedimentation in a deepening sea which seems to have transgressed southward on to the platform of the Sahara only locally (Saharan Atlas, Tripolitanian coast). The Jurassic development of Barbary and of the northern Saharan fringe therefore differed from that of the Levant in certain particulars; in both there were ingressions accompanied by thick limestones, and between them continental north Africa was probably dry land.

Much uniformity is to be observed in Cretaceous development. Aptian - Albian transgression appears from north Sinai across Palestine to the Lebanon; southern Sinai and Transjordan were still continental, but the sea penetrated into them in the Upper Cretaceous, in part only in the Upper Cenomanian : it does not seem to have invaded the Arabian Central mass. The Upper Cretaceous dolomite is thick in Palestine, in western Transjordan the beds are thin and sublittoral; the Senonian-Maestrichtian being phosphatic and including abundant cherts. There was Upper Cretaceous vulcanicity in Transjordan.

In north Africa transgression was widespread from Egypt to the Atlantic, giving rise to shales, marls and limestones, and penetrating to the continental interior. In Egypt the Lower Cretaceous is slightly exposed only in the north, the Upper Cretaceous Cenomanian and Turonian transgressed farther to the south, and the Senonian - Maestrichtian includes the most southerly outcrops. Their littoral phosphatic beds can be traced eastward into Sinai, Transjordan and Syria and westward across the Libyan desert. Nubian facies and lagoonal deposits were developed over the continental surfaces near and inland of the Cretaceous shores. The history of Cretaceous transgression was broadly similar in Egypt, Libya, and the northern Sahara.

Similar conditions also obtained over the southern (Saharan) part of Barbary; but in the northern part (Tell Atlas), bathyal (Tethys) sediments accumulated.

The passage from Cretaceous to Palæogene introduces a number of small but important changes. In Palestine and adjacent territories sediments were laid down in deep bays bounded by land swells (bituminous chalk series): vertical movements therefore gave rise to gaps and discordances in Danian, Eocene and Oligocene beds. In two great north African embayments, Egypt-Libyan desert and Sirtica, Lower Eocene chiefly nummulitic limestones followed the Cretaceous, though the conformity between them is not perfect, and in the Tertiary gulf of Sirtica the Lower Eocene rests on Palæozoic and Mesozoic continental deposits. The Middle and Upper Eocene seas retreated northward to such an extent that the Oligo-Miocene shore line ran from the region of Cairo roughly westward nearly to Tripoli : the regions of the great Cretaceous-Lower Eocene shelf seas were land once more, with continental deposits of Nubian facies and notable cobble beds made of Eocene cherts.

Farther west, in the Sahara, end-Cretaceous regression was final : there was no major Eocene transgressive sea but only shrinking AlgerianTunisian and western Moroccan bays with their valuable Cretaceous - Eocene phosphatic limestones. This marked dissimilarity with the east is associated with the convulsion of the Tethyan geosyncline and the creation, in part, of the Atlas mountain system, of flysch and bathyal deposits, largely at the expense of the northern shield rocks and their blankets of
Mesozoic sediments; the bathyal Mesozoic beds of the geosyncline itself were also involved.

The movements responsible for the Cretaceous Eocene disconformities, local and highly variable in their magnitude and significance between Saharan Barbary and the Levant, are no doubt related to that convulsion, but they are epeirogenic discordances, as Picard points out, remote from the geosyncline, devoid of a flysch facies; and their influence, mainly pre-Eocene, may also account for many changes of Mesozoic facies, both marine and continental.

In Palestine the rhythm of up-and-down movements was interrupted by a short-lived Lower Miocene (Burdigalian) phase of tangential folding, immediately succeeded by renewed uplift, extensive fracturing, block-movements, and some volcanic activity. Still greater uplift followed in the Pontian and in pronounced form at the end of the Pliocene. Picard remarks that the last of these transferred the Burdigalian fold-ranges into upwarp arches and downwarp basins. There is much that points to the Burdigalian of the Levant marking a major orogenic break between Palæogene and Neogene, the varied and thick inland deposits of which may be related to those of Iraq and adjacent territories. Already in Miocene times the fractures induced the formation of graben which, with the folding troughs, formed inland basins. Miocene to Pleistocene cycles of sedimentation took place in these basins, the tectonics of which, owing to the plasticity of their salt and gypsum, are complicated and of peculiar individuality.

The last major fracture phase in Palestine occurred between the Old and Middle Pleistocene and was accompanied by thick and widespread basaltic flows which have preserved large areas of the old land surface : movement has not yet ended. The Quaternary deposits of Palestine are therefore a legacy of the Miocene, and in the several distinct basins, especially that of the Jordan, their history can be traced in considerable detail.

On the Palestinian coast marine Neogene ingressions (Vindobonian, Astian) formed narrow embayments : there was no longer deep transgression over Transjordan. On the whole the Neogene, and perhaps the Oligocene, marked a great regression, with minor oscillations.

It is difficult at present to give an entirely satis. factory review of the north African Neogene development because much of it is still open to debate. It is well known that a much broken area lies between the Gulf of Suez and the Nile valley, in which certainly three directions of faulting may be recognized, in which also folded structures are prominent. Various interpretations have been put upon them: space forbids adequate discussion of a considerable controversy. Perhaps all that is vital and not controversial can be put in a few sentences. Oligo-Miocene or Burdigalian deposits both here and as far as Cyrenaica chronicle primarily destruction of the land by subaerial denudation : some of the beds may be marine, some fluviatile, and there are doubtless gaps in the sequence. Middle and Upper Miocene beds are mainly shallow-water marine limestones and marls. There were important Oligo-Miocene or Miocene basalt flows and sills. A conservative view of the fractures east of the Nile to Sinai is that they owe their origin to movement of blocks, that some of them are pre-Miocene, and that these made way for Miocene ingression, as in the Gulf of Suez, but that some of them are post-Miocene. Folds, some of them spectacular, may be related to bending induced 
by faulting, but from eastern Egypt to the Libyan desert there are marked undulations running northeast - south-west across the broadly longitudinal swells. These remarks may apply in modified form to Cyrenaica. Between the Nile and Cyrenaica the country does not seem, on the whole, to have been so severely broken. West of Suez along the Egyptian coast fracturing probably ended before the Pliocene, or in its earliest stages. There was a period of great volcanic activity, of Tertiary to Recent age, in the interior.

Pliocene beds lie unconformably upon various Tertiary rocks. Important ingressions and regres. sions took place within the Pliocene itself, especially in Egypt, followed by lesser marine oscillations, finally recessive, in the Pleistocene.

From these facts, it may be implied that north Africa felt the repercussions of the Neogene upheavals in the geosynclinal Tethys, and reacted to them in a distinctive and recognizable manner. In Barbary the final stages of mountain building were enacted, accompanied by the exclusion of the Neogene gulfs from among the major mountain elements of the Tell. It was a long process, which contrasts sharply with the peculiar Burdigalian folding phase recognized in Palestine.

\section{OBITUARIES}

\section{His Grace the Archbishop of Canterbury}

The death on October 26 of Dr. William Temple, Archbishop of Canterbury, was a sad blow not only to his intimates and his Church, but also to the rest of the nation and, indeed, the whole world. In the short two years of his primacy, Dr. Temple had earned and gained a unique place in the affection and regard of the people. Although erudite he was no dreary scholar; although deeply religious he was not sanctimonious; although a man of high standards he was charitable to others.

Much has been made in recent years of 'the conflict between science and religion', and the friction of this conflict has engendered more heat than light. The difficulty has been that so few men of science have understood religion, and most churchmen have been ignorant of science. William Temple bridged this intellectual gap and, perhaps even more im. portant, bridged the gap in social intercourse. His years at Manchester and York gave him many opportunities to make contact with men and scientific organizations, and he made the most of them. His appreciation of science was well disclosed in his sermon in Manchester Cathedral before the Victoria University of Manchester during its jubilee celebrations in 1929. Then he emphasized the essential need for universities to foster scientific research alongside scientific training.

It was, however, since his translation to Canterbury in 1942 that Dr. Temple took the most active interest in the field of the social sciences. Especially valued was his help in the work of the Central Council for Health Edueation, of which he was president. His influence and prestige were invaluable, but he was no mere letter-heading. His conduct of the meetings of the Council was a model of chairmanship, and many passages were eased by his urbane humour and kindly wit.

Dr. Temple was truly a spiritual leader, but in the more everyday practical problems of human society he also took a leading part. He got, and helped others to get, at the roots of certain evils of social and industrial life. He realized that here were problems of the spirit, for the understanding of which a widespread general education is necessary before any attempt can be made at their solution. $\mathrm{He}$ held an important position in the Workers' Educational Association, being its president for sixteen years (1908-24). His very practical philosophy comes out in all his well-known books, but perhaps more than elsewhere in his Gifford Lectures of 1932-33 and 1933-34 on "Nature, God and Man", in which he pleaded for dialectical realism as opposed to the dialectical materialism of Marx. Onwards from then, and especially at the Malvern Conference, his sermons, addresses and writings convinced a wide public that the Church is not concerned with "another world" but is a strong social force in this. As The Times said : "he was a philosopher whose mind had been deeply given not only to classical studies but also to the problems of current thought".

Born in a bishop's palace, and educated at Rugby and Oxford, Dr. Temple yet was one of the common people. He towered above the rest of us, yet neither zppeared himself to be aware of the fact nor did he nake his fellows unduly conscious of it. Truly he vas a leader of men.

\section{Dr. Dorothy Ashworth}

Dr. Dorothy Ashworth, whose untimely death at the age of thirty-six occurred on October 4, was, we had assumed, one of our coming plant pathologists. Her work on plant rusts began at the Royal Holloway College after she graduated from there in 1929, and it was during her second postgraduate year that Dr. Holden, on a visit to the College, saw and appreciated her skilful and immaculate technique in the isolation of sporidia and her inoculations with single sporidia. She was, in the following year, awarded a research studentship at University College, Nottingham, and continued the work in Prof. Holden's laboratory. The next year found her working in the Cryptogamic Laboratory of the University of Manchester, and from there she passed to the laboratory of the Royal Horticultural Society's Gardens at Wisley as assistant mycologist. Her work has been characterized throughout by exceptional thoroughness and sincerity. Her modest, unassuming manner masked a critical approach, sound judgment and a firm opinion. Her composed demeanour covered a meticulous care of the material in her charge and a constant watchfulness. There was no impatience for results, no haste to publish. Her attitude was simply that of a student seeking the truth. Science can ill spare such a faithful servant.

E. M. Blackwell.

Dr. Ashworth joined the staff of the Royal Horticultural Society at Wisley Laboratory in the summer of 1935 as assistant to the mycologist. Before this her work had been concerned with pure research on various rust fungi, but she quickly adapted herself to the practical problems of horticultural plant diseases, and besides continuing valuable studies on various fungus parasites, notably the Antirrhinum' rust fungus, Puccinia Antirrhini, rendered valuable assistance in the experiments on methods of control of diseases in certain ornamental and crop plants. 